\title{
Axitinib induces senescence-associated cell death and necrosis in glioma cell lines: The proteasome inhibitor, bortezomib, potentiates axitinib-induced cytotoxicity in a p21(Waf/Cip1) dependent manner
}

\author{
Maria Beatrice Morelli1,2, Consuelo Amantini ${ }^{3}$, Massimo Nabissi ${ }^{1}$, Claudio Cardinali ${ }^{1,2}$, \\ Matteo Santoni ${ }^{4}$, Giovanni Bernardini ${ }^{2,5}$, Angela Santoni ${ }^{2,5}$, Giorgio Santoni ${ }^{1}$ \\ ${ }^{1}$ School of Pharmacy, University of Camerino, Camerino, Italy \\ ${ }^{2}$ Department of Molecular Medicine, Sapienza University, Rome, Italy \\ ${ }^{3}$ School of Biosciences and Veterinary Medicine, University of Camerino, Camerino, Italy \\ ${ }^{4}$ Department of Medical Oncology, Polytechnic University of Marche, Ancona, Italy \\ ${ }^{5}$ I.N.M. Neuromed, Pozzilli, Isernia, Italy \\ Correspondence to: Giorgio Santoni, email: giorgio.santoni@unicam.it \\ Keywords: axitinib, glioblastoma, bortezomib, p21, senescence
}

Received: August 02, $2016 \quad$ Accepted: November 18, 2016

Published: December 01, 2016

\section{ABSTRACT}

Glioblastoma is associated with a poor overall survival despite new treatment advances. Antiangiogenic strategies targeting VEGF based on tyrosine kinase inhibitors (TKIs) are currently undergoing extensive research for the treatment of glioma.

Herein we demonstrated that the TKI axitinib induces DNA damage response (DDR) characterized by $\mathrm{Y}-\mathrm{H} 2 \mathrm{AX}$ phosphorylation and Chk1 kinase activation leading to G2/M cell cycle arrest and mitotic catastrophe in U87, T98 and U251 glioma cell lines. Moreover, we found that p21(Waf1/Cip1) increased levels correlates with induction of ROS and senescence-associated cell death in U87 and T98 cell lines, which are reverted by $\mathrm{N}$-acetyl cysteine pretreatment. Conversely, U251 cell line showed a resistant phenotype in response to axitinib treatment, as evidenced by cell cycle arrest but no sign of cell death.

The combinatorial use of axitinib with other therapies, with the aim of inhibiting multiple signaling pathways involved in tumor growth, can increase the efficiency of this TKI. Thus, we addressed the combined effects of axitinib with no toxic doses of the proteasome inhibitor bortezomib on the growth of U87 and T98 axitinibsensitive and axitinib-resistant $\mathrm{U} 251$ cell lines. Compared to single treatments, combined exposure was more effective in inhibiting cell viability of all glioma cell lines, although with different cell death modalities. The regulation of key DDR and cell cycle proteins, including Chk1, y-H2AX and p21(Waf1/Cip1) was also studied in glioma cell lines.

Collectively, these findings provide new perspectives for the use of axitinib in combination with Bortezomib to overcome the therapy resistance in gliomas.

\section{INTRODUCTION}

Glioblastoma (GBM) is a high angiogenic malignancy. GBM secretes high levels of vascular endothelial growth factor (VEGF) that promotes endothelial cell proliferation, blood brain barrier permeability and angiogenesis $[1,2]$. They are aggressive tumors that generally respond poorly to therapy consisting of surgery, radiation, and conventional chemotherapy. Although advancements in the past decades, no significant increase in the overall survival (OS) of patients is observed, with a median survival of 14.6 months and five-year survival $<10 \%$ [3]. Molecularly targeted agents hold significant promise as novel therapeutic adjuncts; however, these new therapies are still in clinical trial phase. Among targeted therapies, a new current focuses on 
the angiogenic tyrosine kinase receptors (TRKs) and their signaling pathway inactivation. The anti-VEGF antibody bevacizumab was the first TKI approved in 2009 by the Food and Drug Administration (FDA) as a second-line treatment of recurrent GBM [4].

A novel orally available TKI is axitinib (Inlyta $($ ), a selective and potent inhibitor of VEGFR 1, 2, and 3 that has been approved by FDA in 2012 for the treatment of patients with metastatic renal cell carcinoma (mRCC) after failure of one prior systemic therapy [5, 6]. We have recently reported that axitinib induces activation of DNA damage response (DDR), senescence and mitotic catastrophe in RCC cell lines [7]; however at present, very few data using this TKI have been provided in GBM. Preclinical study showed that systemic treatment with axitinib exerts antiangiogenic effect and survival prolongation in preclinical orthotopic GBM models, including clinically relevant glioma stem cell models [8]. More recently, a randomized multicenter phase II clinical trial demonstrated an increased 6-month progressionfree survival (PFS) rate of $34 \%$ after axitinib treatment in patients with recurrent GBM with respect to $28 \%$ PFS in the control patients treated with bevacizumab or lomustine, suggesting that in recurrent GBM, axitinib shows clinical activity as single-agent [9]. Finally, a window study on front-line axitinib followed by axitinib and radiation in elderly patients with glioblastoma from University of Cincinnati (NCT01508117) is currently under evaluation.

Other new-targeted therapies interfere with proteasome, the enzymatic complex responsible for the bulk of protein degradation. Proteasome inhibition leads to toxic accumulation of misfolded and abnormal proteins and can also stabilize specific tumor inhibitory factors such as cell cycle regulatory proteins and induce apoptosis [10-14]. The proteasome inhibitor bortezomib (PS-341/Velcade) is FDA-approved for multiple myeloma and mantle cell lymphoma [15]. Bortezomib functions as a selective inhibitor of the $26 \mathrm{~S}$ proteasome, producing predictable, dose-related, and reversible proteasome inhibition [16]. It exerts antitumor activity in a variety of malignancies [17]. In vitro studies have demonstrated that bortezomib alone or in combination with histone deacetylase (HDAC) [18], the cyclooxygenase-2 inhibitor celecoxib (Celebrex) [19], phosphatidylinositol 3-kinase (ZSTK474) inhibitors [20] or temozolomide [21, 22] stimulates a potent cytotoxic response and causes cell death in GBM cell lines.

Therefore, the aim of the present work was to evaluate the effects of axitinib treatment as monotherapy and in combination with bortezomib on multiple signaling pathways involved in glioma growth. Of particular interest was the cytotoxic synergy of axitinib-bortezomib combination found in different human glioma cell lines that involves the modulation of $\mathrm{p} 21$ (Waf1/Cip1) protein levels and leads to enhanced cell death.

\section{RESULTS}

\section{Axitinib inhibits glioma cell viability in a dose and time-dependent manner}

We first evaluated the effects of axitinib on cell viability in U87, T98 and U251 glioma cell lines by performing dose-response and time-course analyses (Supplementary Figure S1A). Axitinib inhibited the growth of U87 and T98 cells, after $72 \mathrm{~h}$ of treatment, with $\mathrm{IC}_{50}$ values of $12.7 \mu \mathrm{M}$ and $8.5 \mu \mathrm{M}$, respectively (Figure 1). Conversely, U251 cells were found to be more resistant to axitinib-mediated cytotoxic effects. Therefore, the lowest effective dose of axitinib in inducing growth inhibition for each cell line ( $5 \mu \mathrm{M}$ for U87 and T98; 15 $\mu \mathrm{M}$ for $\mathrm{U} 251$ ) was used for the subsequent experiments.

\section{Axitinib triggers the DNA damage response (DDR) and p21 overexpression in glioma cell lines}

Axitinib has been found to trigger DDR in RCC lines [7], however at present no data on the effect of axitinib in glioma are available. Thus, to evaluate whether axitinib treatment could trigger the DDR in glioma cells, we initially investigated the presence of $\gamma$-H2AX (H2AX), Ser139 phosphorylated variant of histone 2A associated with DNA double-strand breaks [23]. Western blot analysis revealed strong induction of
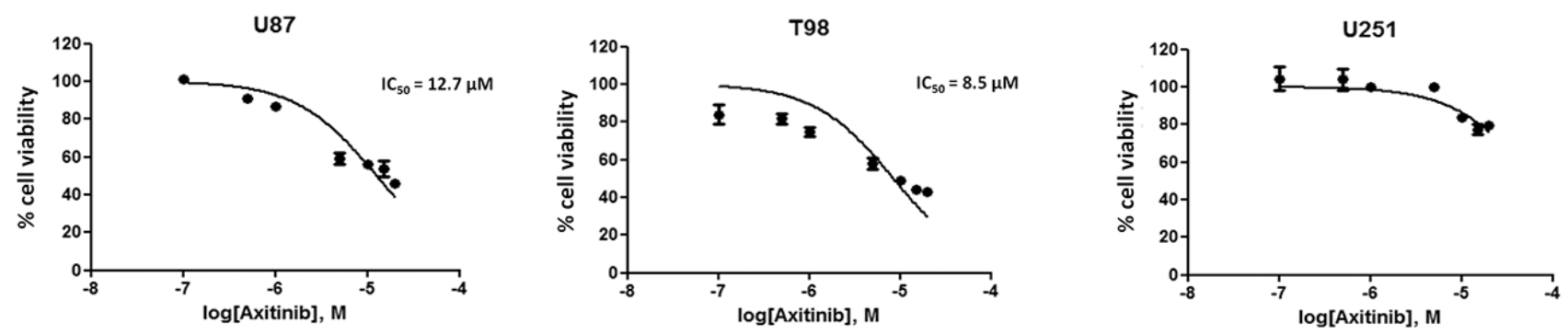

Figure 1: Axitinib inhibits viability in glioma cell lines. U87, T98 and U251 glioma cell lines were cultured for $72 \mathrm{~h}$ with different doses of axitinib. Cell viability was determined by MTT assay. Data shown are expressed as mean \pm SE of three separate experiments. 
the DNA damage marker expression in all axitinib-treated glioma cell lines, although with different kinetics (Figure $2 \mathrm{~A}$ and $2 \mathrm{~B}$ ). Interestingly, phospho-H2AX induction was accompanied by Ser345-Chk1 phosphorylation already at $3 \mathrm{~h}$ after exposure to axitinib that declined at later time points in all glioma cell lines. The Chk1 protein was expressed in all glioma cell lines until $48 \mathrm{~h}$, and declined at later time points after axitinib treatment (Figure 2A and $2 \mathrm{~B}$ ). At $12 \mathrm{~h}$ after treatment, p21 overexpression, that paralleled the decline of Ser345-Chk1 activation, was observed in U87 and T98 cells, but not in U251 cells (Figure 2A and 2B).

\section{Axitinib induces G2/M arrest and mitotic catastrophe in glioma cell lines}

Then we evaluated whether axitinib treatment could result in cell cycle alteration. Thus, we performed cell cycle experiments in the presence of axitinib for different times. We observed that treatment of glioma cells induced a significant early (just at $6 \mathrm{~h}$ ) and transient decrease of G1-phase which was accompanied by a progressive increase of G2/M-phase cell population until $24 \mathrm{~h}$ in U87, T98 glioma cells and $72 \mathrm{~h}$ in U251 (Figure 2C and Supplementary Figure S1B). In addition, a decreased percentage of U87 and
T98, but not U251 cells in G2/M-phase cells paralleled by an increase of subG1 phase was observed at 48-72 h after axitinib treatment (Figure 2C and Supplementary Figure S1B). Moreover, treatment with axitinib led to a significant increase in the percentage of cells with polyploidy in all glioma cell lines analyzed (cells with DNA content $>4 \mathrm{~N}$ ) (Figure 2C and Supplementary Figure S1B).

Tetraploid tumor cells intrinsically susceptible to mitotic aberrations are particularly sensitive to the induction of mitotic catastrophe [24, 25]. Thus, we decided to investigate whether axitinib treatment could result in mitotic catastrophe in glioma cells, by assessing the changes in nuclear morphology [26]. By Hoechst 33258 staining we observed that the nuclei became significantly larger and some cells contained several nuclei of unequal sizes already after $24 \mathrm{~h}$ of drug treatment in U87, T98 and U251 glioma cell lines (Figure 3A). Further, in order to assess mitochondrial changes in mitotic catastrophe, JC-1 staining was used to analyze mitochondrial mass. As shown in Figure $3 \mathrm{~B}$ and $3 \mathrm{C}$, an increase of FL-1 green fluorescence in axitinib treated compared to untreated glioma cells, resulting by enhanced mitochondrial mass, was observed. This data was also confirmed by NAO staining [27] (Supplementary Figure S1C).

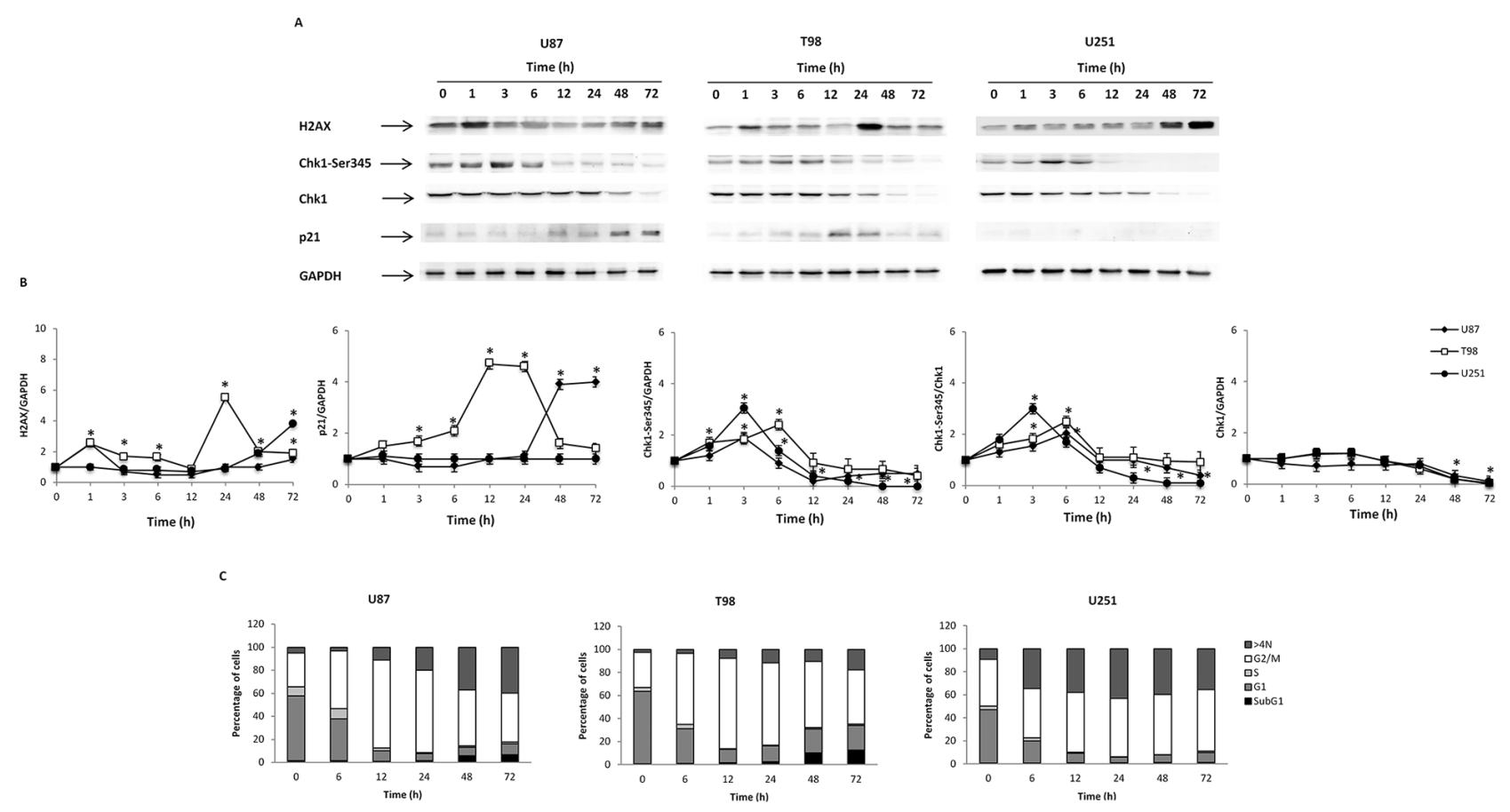

Figure 2: Axitinib induces DNA damage response and cell cycle arrest. A. Western blot analysis of H2AX, Chk1-Ser345, Chk1 and p21 protein levels in glioma cells after $72 \mathrm{~h}$ treatment with $5 \mu \mathrm{M}$ axitinib for U87 and T98 cells, and with $15 \mu \mathrm{M}$ axitinib for U251. Blots are representative of one of three separate experiments. B. H2AX, Chk1-Ser345, Chk1 and p21 densitometry values were normalized to GAPDH used as loading control. The Chk1-Ser345 protein levels were also determined with respect to Chk1 levels. Densitometric values shown are the mean \pm SD of three separate experiments. ${ }^{*} \mathrm{p}<0.01$ vs untreated cells. C. Cell cycle analysis in U87 and T98 cells treated with $5 \mu \mathrm{M}$ axitinib and in $\mathrm{U} 251$ cells treated with $15 \mu \mathrm{M}$ axitinib for the indicated times. 


\section{Axitinib triggers senescence-associated cell death and necrosis in U87 and T98 glioma cell lines}

Cell cycle arrest in G2/M phase and polyploidy often result in cellular senescence [28]. Thus, a timedependent accumulation of glioma cells with enlarged and flattened morphology was observed after axitinib treatment by microscopy analysis (Figure 4A). Since these morphological changes are reminiscent of a senescent phenotype, we analyzed the activity of senescenceassociated $\beta$-galactosidase (SA- $\beta$-gal), the typical marker of senescent cells, in glioma cells after axitinib treatment $[29,30]$. Forty-eight hours after treatment, the increase on SA- $\beta$-gal activity was detected by flow cytometry using the fluorogenic substrate for SA- $\beta$-galactosidase, $\mathrm{C}_{12} \mathrm{FDG}$, and reached the percentage of 51 and 75 in U87 and T98 cells, respectively at $72 \mathrm{~h}$ of treatment (Figure 4B). These results were also confirmed by cytochemical assessment of SA- $\beta$-gal activity that revealed the presence of blue-stained U87 and T98 glioma cells after treatment with axitinib (Figure 4C). No SA- $\beta$-gal-positive senescent cells were found in axitinib-treated U251 glioma cells (Figure 4B, 4C).

Recent studies have suggested that reactive oxygen species (ROS) generation triggered by anti-cancer drug can stimulate cellular senescence [31, 32]. Thus, we evaluated the capability of axitinib to trigger ROS generation in glioma cells by flow cytometry using the general redox-sensitive fluorescent dye, DCFDA. As shown in Figure 5A, axitinib stimulated intracellular ROS generation in U87 and T98, but not in U251 glioma cells. It was evident at $24 \mathrm{~h}$ after exposure and progressively increased at later time points. This response was reverted by the pre-treatment of glioma cells with the ROS scavenger, N-acetyl-1-cysteine (NAC) (Figure 5B).

Depending whether it is replicative or premature, cellular senescence may also affect cell viability $[33,34]$. Thus, we evaluated the effect of axitinib exposure on glioma cell viability by SA- $\beta$-gal/PI staining and FACS analysis. An increased number of SA- $\beta$-gal ${ }^{+} \mathrm{PI}^{+}$and SA-
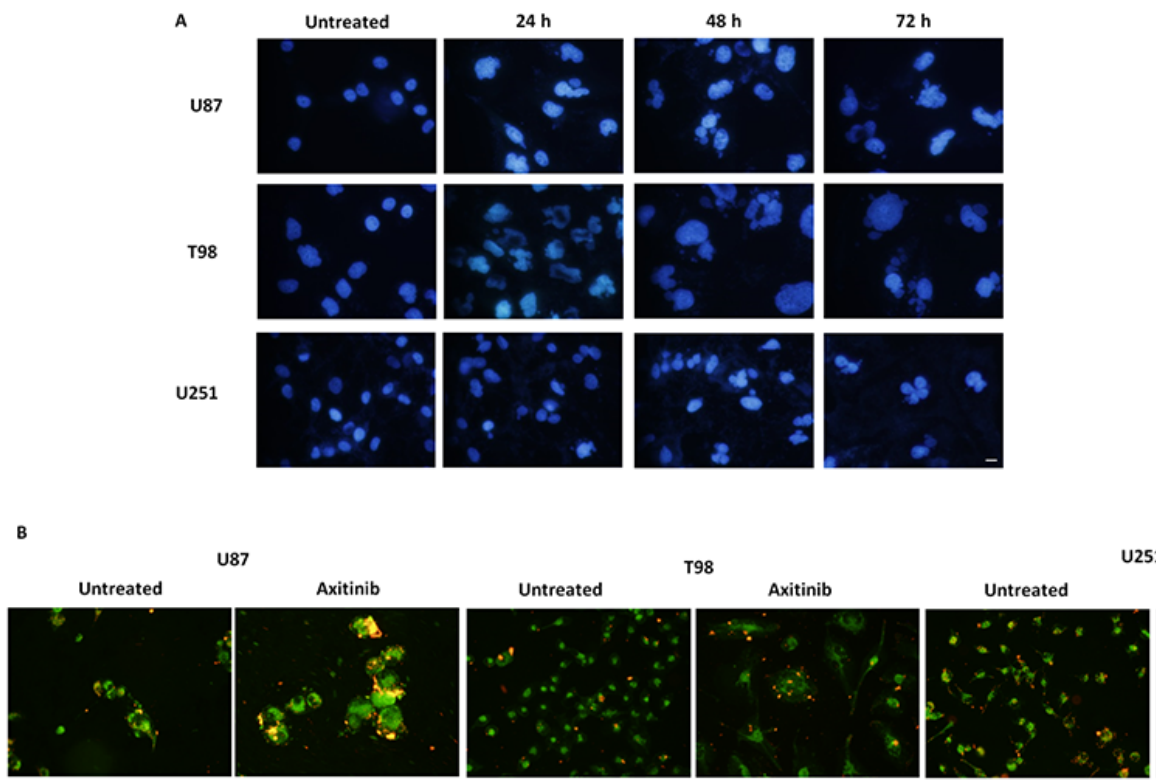

U251
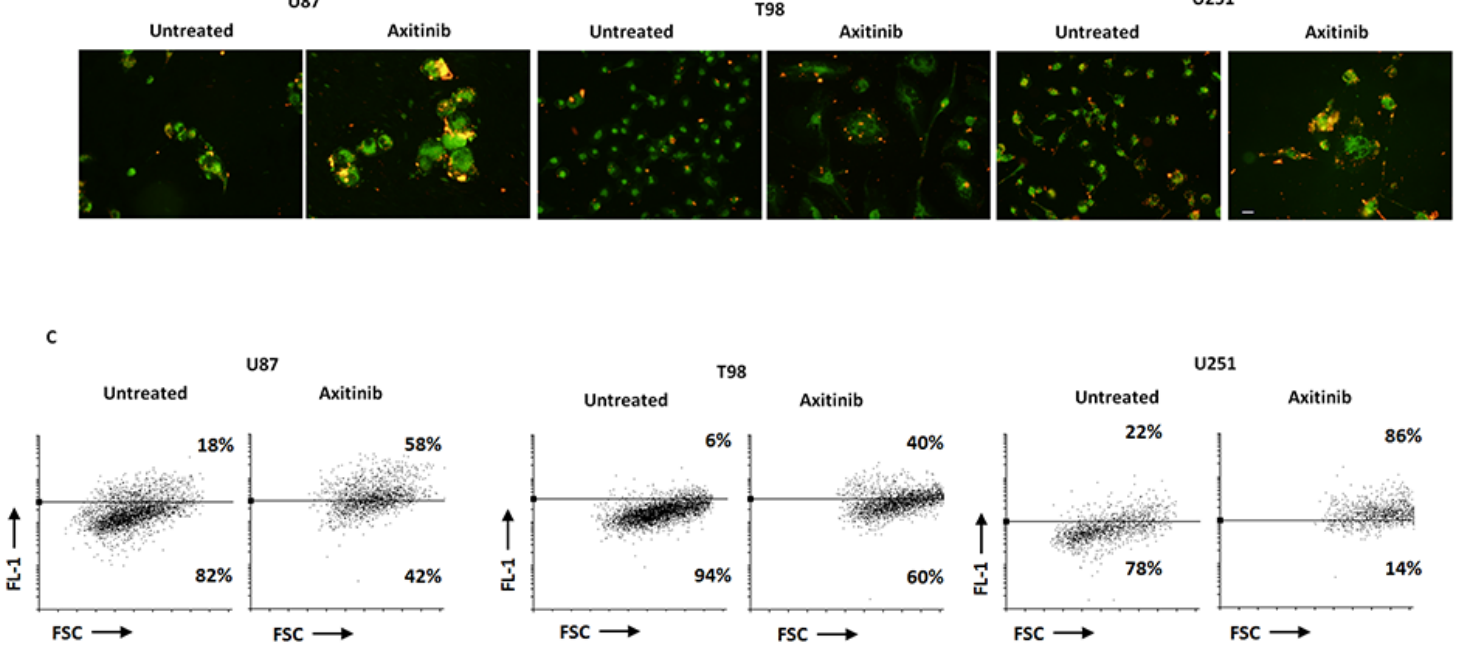

Figure 3: Axitinib triggers mitotic catastrophe in all glioma cell lines. A. Nuclei of glioma cells untreated or treated with axitinib for the indicated time were stained with Hoechst 33258 and then analyzed on ten random fields. Cells were observed under a fluorescence microscope. Bar: $30 \mu \mathrm{m}$. B. Fluorescence microscope images show increase of green fluorescent signal upon axitinib treatment after $72 \mathrm{~h}$ compared to untreated cells. Bar: $30 \mu \mathrm{m}$. C. Change in JC1 green (FL-1) with respect to FSC parameter in cells treated with axitinib for 72 $\mathrm{h}$ was detected by flow cytometer. 
$\beta$-gal-PI ${ }^{+}$cells, suggestive of premature senescence and necrotic cell death, respectively, was observed in U87 cells after axitinib exposure, whereas axitinib-treated T98 cells showed a SA- $\beta$-gal ${ }^{+} \mathrm{PI}^{+}$phenotype (Figure $5 \mathrm{C}$ ). Neither premature senescence or necrotic cell death were identified in axitinib-treated U251 cells (Figure 5C). Moreover, pre-treatment of axitinib-administered U87 and T98 glioma cells with NAC reduced the percentage $\beta$-gal ${ }^{+} \mathrm{PI}^{+}$in axitinib-treated cells, whereas no changes in NAC-treated cells were observed (Figure 5C).
Altogether, the high percentage of SA- $\beta$-gal ${ }^{+} \mathrm{PI}^{+} \mathrm{U} 87$ and T98 cells suggested that these two cell lines undergo to senescence-associated cell death, and the ROS generation is indispensable for the induction of this process. On the contrary in U251 glioma cells, the inability of axitinib to trigger ROS production results in a failure to induce premature senescence and cell death. Furthermore, the lack of Annexin $\mathrm{V}^{+}$cells and caspase-3 activation up to 72 $\mathrm{h}$ of axitinib treatment evidenced a necrotic cell death in U87 and T98 cells (Supplementary Figure S1D, 1E).
A

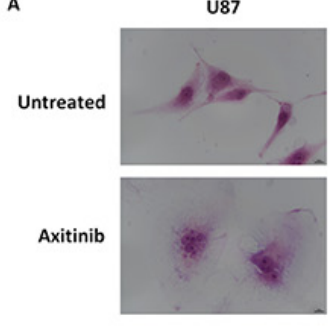

U87

B

$24 \mathrm{~h}$

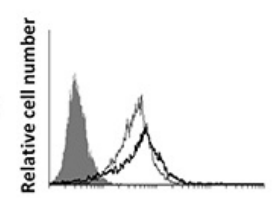

T98
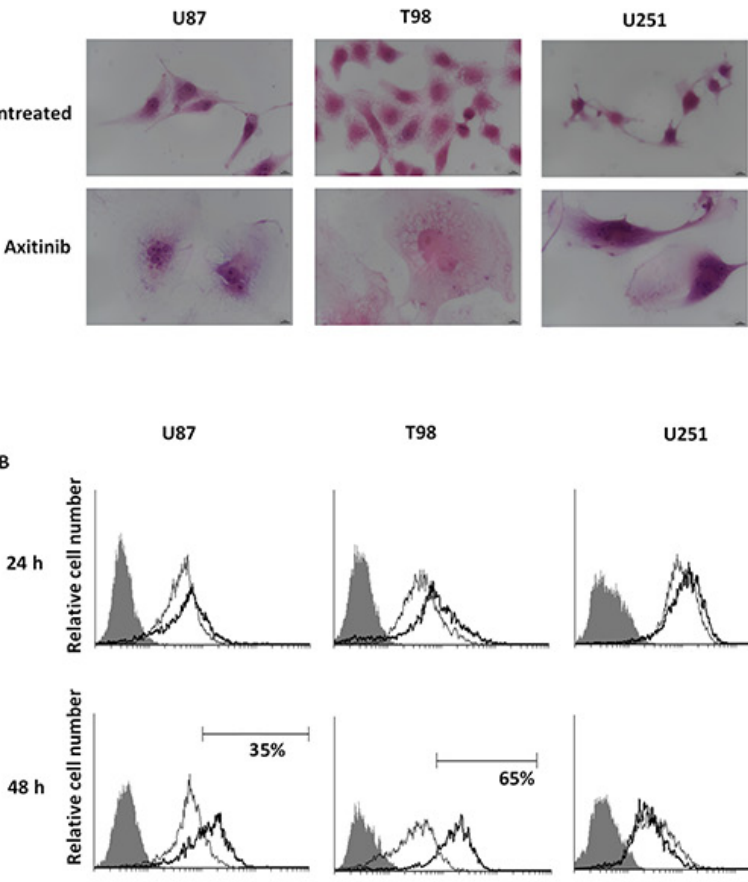

$72 \mathrm{~h}$

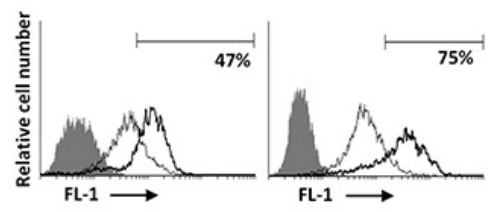

c
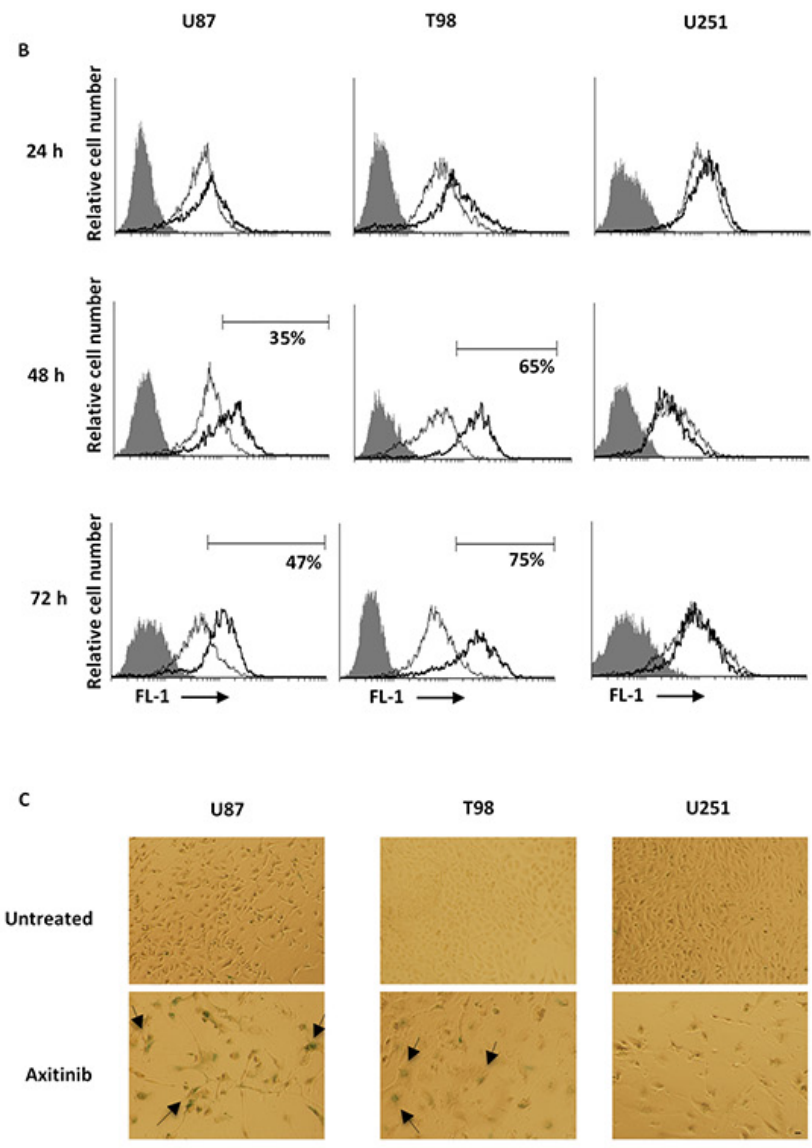

anstained control

$\square$ Untreated
$\square$ Axitinib

Figure 4: Axitinib induces cellular senescence in U87 and T98, but not in U251 glioma cell lines. A. Representative image of glioma cells $72 \mathrm{~h}$ after treatment with axitinib and then stained with haematoxylin and eosin (H\&E). Bar: $10 \mu \mathrm{m}$. B. Representative flow cytometric profiles of glioma cells untreated or treated with axitinib ( $5 \mu \mathrm{M}$ for U87 and T98 cells and 15 $\mu \mathrm{M}$ for U251), then stained with $\mathrm{C}_{12} \mathrm{FDG}$, a fluorogenic substrate for SA- $\beta$-galactosidase before analysis. Data represent the percentage of positive cells. Grey curve represents unstained cells. C. Cellular senescence was assessed in glioma cells after $72 \mathrm{~h}$ of axitinib treatment by cytochemistry detection of SA- $\beta$-galactosidase activity. Bar: $20 \mu \mathrm{m}$. 
To elucidate whether axitinib treatment was able to select resistant glioma cells, the ability to resume proliferation was evaluated. To this purpose U87, T98 and U251 cell lines were incubated with axitinib for $72 \mathrm{~h}$ and at the end of the treatment the viable cells remained were washed to remove axitinib, replated and incubated for additional days in fresh media. After axitinib removal, only U251 cells showed the ability to restart to growth although at lower degree respect to untreated cells (Supplementary Figure S2A). Moreover, data obtained by staining for SA- $\beta$ Gal/PI incorporation showed an increased percentage of SA- $\beta \mathrm{Gal}^{+} / \mathrm{PI}^{+}$and $\mathrm{PI}^{+}$cells in $\mathrm{U} 87$ and in T98 cells, respectively. In U251 cells the absence of senescence-associated SA- $\beta$ Gal or PI staining respect to untreated cells after culture in fresh media was observed (Supplementary Figure S2B).

Taken together, these results demonstrated that axitinib induces an irreversible senescence and cell death in U87 and T98 cells. On the other hand, U251 cells are confirmed to show a resistant phenotype.

A

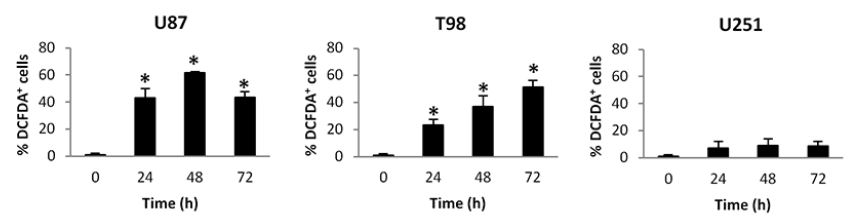

B

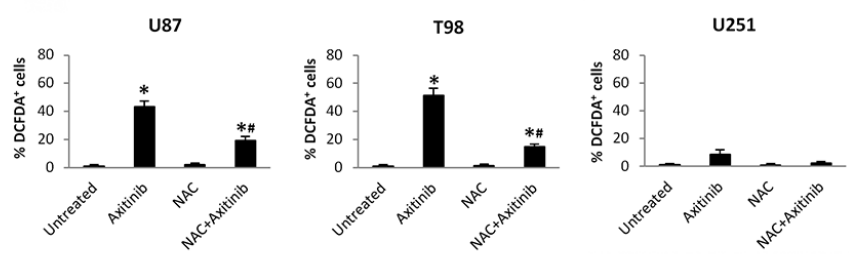

U87

c
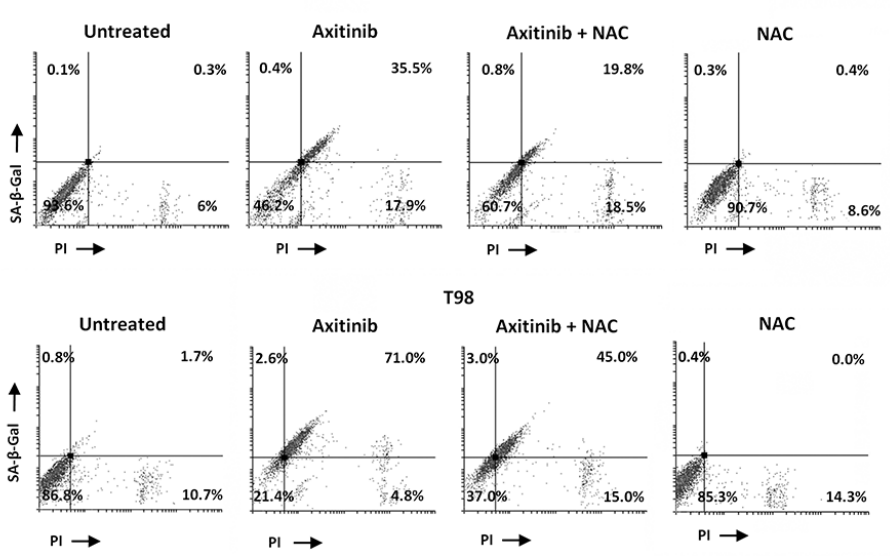

T98
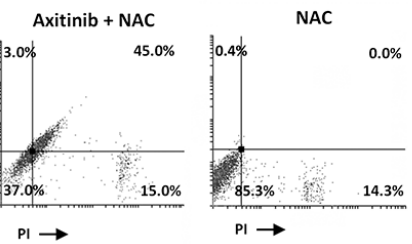

U251

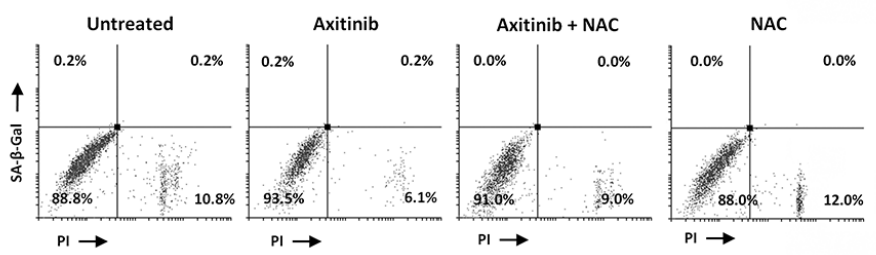

Figure 5: Axitinib induces ROS-dependent senescence-associated cell death in U87 and T98 cell lines. A. ROS generation in glioma cell lines treated with axitinib ( $5 \mu \mathrm{M}$ for U87 and T98 cells and $15 \mu \mathrm{M}$ for U251) for the indicated times. Cells were stained with DCFDA before flow cytometric analysis. Data are expressed as percentage of DCFDA positive cells with respect to untreated cells; * $<$ 0.01 vs untreated cells. B. Glioma cells were pretreated with NAC $10 \mathrm{mM}$ for $1 \mathrm{~h}$ before the administration of axitinib. After $72 \mathrm{~h}$ cells were stained with DCFDA and analyzed as above described. ${ }^{*} \mathrm{p}<0.01 v s$ untreated cells; ${ }^{*} \mathrm{p}<0.01$ vs axitinib or NAC treated cells. C. Glioma cells were cultured with axitinib for $72 \mathrm{~h}$, with or without pretreatment with NAC $10 \mathrm{mM}$ for $1 \mathrm{~h}$. Flow cytometric analysis was performed by $\mathrm{C}_{12}$ FDG and PI double-staining. Data represent the percentage of PI and/or SA- $\beta$-galactosidase positive cells and are representative of one of three separate experiments. 


\section{Overexpression of p21 sensitizes U251 glioma cells to axitinib treatment}

Owing to the potential role of $\mathrm{p} 21$ in the senescence pathway, we evaluated whether overexpression of exogenous p21 would sensibilize axitinib-resistant U251 cells from axitinib-induced cell death. Therefore, we transfected $\mathrm{pCMV}$ vector containing coding sequence for p21 in this cell line, and we investigated the cell viability. Firstly, we evaluated the p21 protein expression in pCMV (transfection control) and pCMV-p21 respect to untransfected U251 glioma cells by western blot analysis. The p21 protein levels were not detectable in untreated and pCMV U251 cells, whereas increased p 21 expression was observed in pCMV-p21 U251 transfected glioma cells (Figure $6 \mathrm{~A}$ ). About $40 \%$ of growth inhibition was observed upon axitinib treatment in pCMV-p21 U251 glioma cells after $72 \mathrm{~h}$ of treatment (Figure 6B). In addition, p21 overexpression increased the percentage of cells in subG1 phase respect to U251 pCMV transfected cells (Figure 6C). Whereas in pCMV transfected cells axitinib treatment increased the percentage of cells in $\mathrm{G} 2 / \mathrm{M}$ phase, in pCMV-p21 transfected cells axitinib markedly improved the subG1 phase as compared to untreated cells (Figure 6C). Accordingly, PI staining and cytofluorimetric analysis revealed, an increased percentage (about 50\%) of $\mathrm{PI}^{+}$cells in axitinib-treated pCMV-p21 U251 cells, as compared to untreated pCMV-p21 U251 cells (Figure 6D). However, axitinib-treated pCMV-p21 U251 cells were not Annexin $\mathrm{V}$ positive (Figure $6 \mathrm{E}$ ). No major differences were found upon axitinib treatment in pCMV U251 cells.

Overall, overexpression of $\mathrm{p} 21$ in axitinib-resistant U251 glioma cells overcomes the U251 glioma cell dysfunction, and sensitizes glioma cells to axitinibinduced cytotoxic effects.

\section{Bortezomib in combination with axitinib stimulates a synergistic cytotoxic effect in glioma cell lines}

Bortezomib has been found to induce p21 over expression and apoptotic cell death of glioma cell lines [35]. So, we performed a time course analysis and found that bortezomib reduces the viability in U87, T98 and U251 cells with $\mathrm{IC}_{50}$ values of $3.5 \mathrm{nM}, 4.5 \mathrm{nM}$ and 5.0 $\mathrm{nM}$, respectively (Supplementary Figure S3). Thereafter, to evaluate the potential synergistic effects of axitinib and bortezomib, we performed MTT cell growth assays treating cells with different doses of axitinib $(1,5$ and 15 $\mu \mathrm{M})$ in combination with different doses of bortezomib $(1.25,2.5$ and $6.5 \mathrm{nM})$ for up to $72 \mathrm{~h}$. We evaluated the cell viability on axitinib-sensitive (U87 and T98) and axitinibresistant U251 glioma cell lines in two different schedules. As shown in Supplementary Figure S4, the synergistic effects between axitinib and bortezomib was present only when drugs were simultaneously administered. In sequential regimens, axitinib was added for $72 \mathrm{~h}$, then the viable cells were replated and treated with bortezomib for other $72 \mathrm{~h}$. No improvement of cytotoxic effects was observed, rather the axitinib-pretreated cells were more resistant to bortezomib treatment (Supplementary Figure S4A). In simultaneous regimen, both drugs were added on day 0 and the combined effect was evaluated on the basis of the CI (Supplementary Figure S4B). The CI results showed synergism when axitinib and bortezomib are coadministered and the lowest dose of bortezomib displaying a $\mathrm{CI}<1(2.5 \mathrm{nM})$ was selected to study the cytotoxic effects of simultaneous treatment. To ensure that this dose was not cytotoxic, we performed several experiments. Our results demonstrated that bortezomib used at $2.5 \mathrm{nM}$ does not induce mitotic catastrophe as evaluated by nuclear morphology and mitochondrial mass (Supplementary Figure S5A-B), does not alter cell cycle phases (Supplementary Figure S5C), does not induce ROS generation (Supplementary Figure S5D) or cell senescence process (Supplementary Figure S5E), does not exert cytotoxic effects as evaluated by Annexin V-PI double staining (Supplementary Figure S5F) and does not change the VEGFA mRNA levels (Supplementary Figure S5G).

\section{Effects of the axitinib-bortezomib combination on cell death signaling pathways}

Axitinib plus bortezomib coadministration for $72 \mathrm{~h}$ synergized to increase cytotoxic activity against glioma cells, as compared to axitinib alone, with a 5 - and 10 -fold reduction of the $\mathrm{IC}_{50}$ in $\mathrm{U} 87$ and $\mathrm{T} 98$ glioma cells $\left(\mathrm{IC}_{50}\right.$ axitinib $=12.7$ and 8.5 vs $\mathrm{IC}_{50}$ axitinib-bortezomib $=3.4$ and $0.9 \mu \mathrm{M}$ in U87 and T98 glioma cells, respectively) (Figure 7A). Furthermore, axitinib in combination with bortezomib reverted the resistance of U251 glioma cells to axitinib treatment alone and inhibited U251 glioma cell viability with an $\mathrm{IC}_{50}$ value of $8.8 \mu \mathrm{M}$ (Figure 7A).

To investigate the synergistic mechanism, we evaluated the effects of bortezomib $(2.5 \mathrm{nM})$ coadministered with the lowest effective dose of axitinib (5 $\mu \mathrm{M}$ in $\mathrm{U} 87$ and $\mathrm{T} 98 ; 15 \mu \mathrm{M}$ in $\mathrm{U} 251$ ).

After $72 \mathrm{~h}$, all glioma cell lines underwent mitotic catastrophe, as evidenced by nuclear morphology and mitochondrial mass increase (Figure 7B,7C and Supplementary Figure S6). Moreover, the combination of TKI and proteasome inhibitor highly increased the levels of intracellular ROS activity in U87 and T98 cell lines (Figure 7D) whereas lower ROS levels were observed in axitinib-resistant U251 glioma cells compared to cell treated with axitinib alone (Figure 7D). The ROS production effect was attenuated by NAC pretreatment after $72 \mathrm{~h}$ of treatment (Figure 7D). Furthermore, axitinib plus bortezomib in combination resulted in an increased percentage of $\beta-\mathrm{gal}^{+} \mathrm{PI}^{+}$in U87 and T98 cells and $\beta$-gal-PI ${ }^{+} \mathrm{U} 251$ cells (Figure 7E), as compared to axitinib (Figure 5C) or bortezomib (Supplementary 
Figure S5E,S5F) used alone. Moreover, as described for axitinib monotherapy in T98 and U87, neither Annexin V positive cells, apoptotic DNA fragmentation or caspase-3 activity (Supplementary Figure S7AS7C) were evidenced in axitinib plus bortezomib treated U251 glioma cells. Since U251 cells resumed proliferation after axitinib removal, we investigated if the coadministration of axitinib plus bortezomib was able to induce an irreversible growth arrest.

Thus, U251 cells were treated with both drugs for $72 \mathrm{~h}$, then washed and replated in fresh medium. MTT results showed that the coadministration strongly inhibits the cell growth recovery suggesting that the drug combination is able to overcome U251 resistant phenotype. Bortezomib alone did not affect the rate of growth (Supplementary Figure S7D).

\section{Involvement of p21 in cytotoxicity induced by axitinib plus bortezomib}

The effects of axitinib plus bortezomib used in combination were associated with an enhanced p21 protein levels in all glioma cell lines with respect to cells treated with bortezomib or axitinib alone. No significative changes of Ser345-Chk1 and H2AX phosphorylation were observed (Figure 8A-8D, Supplementary Figure S8).
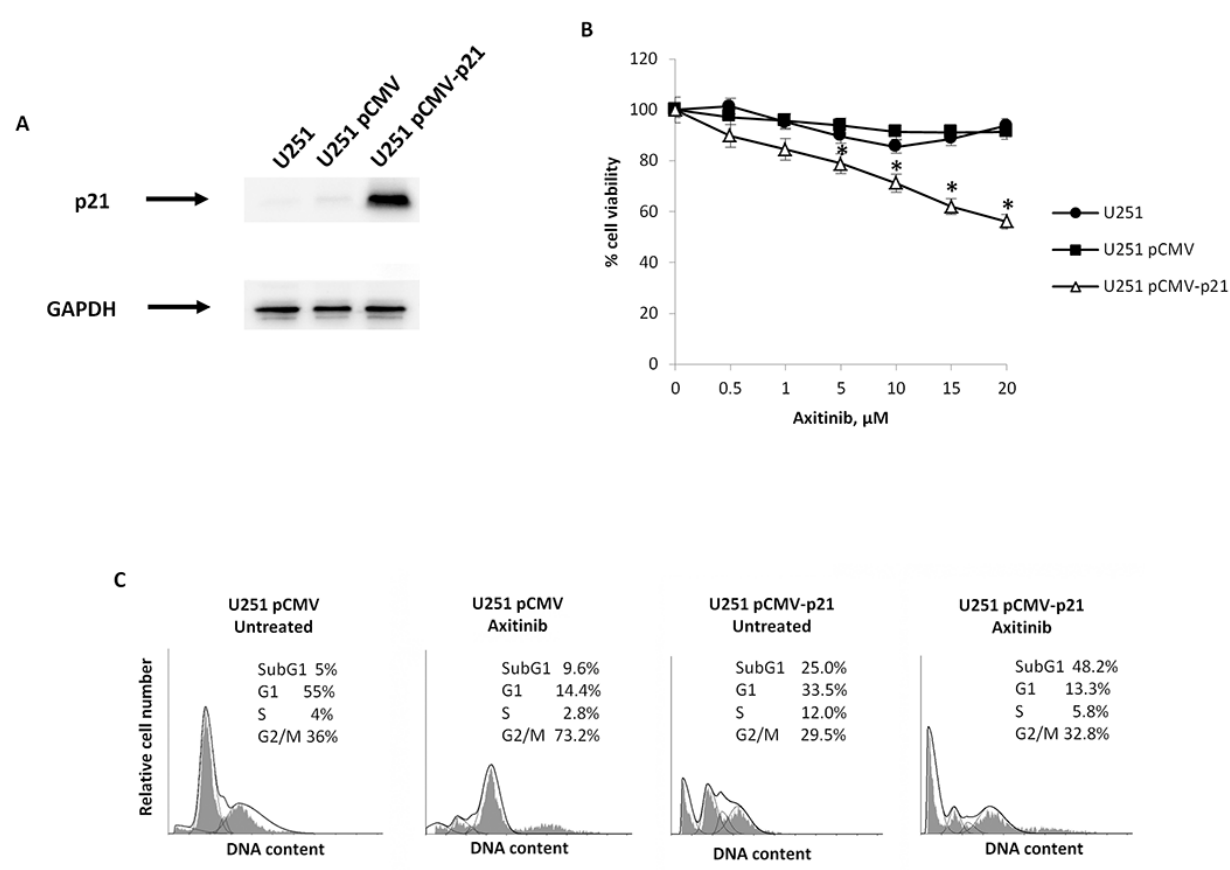

D

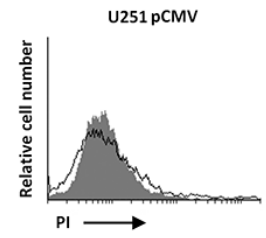

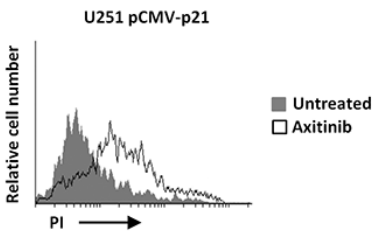

E

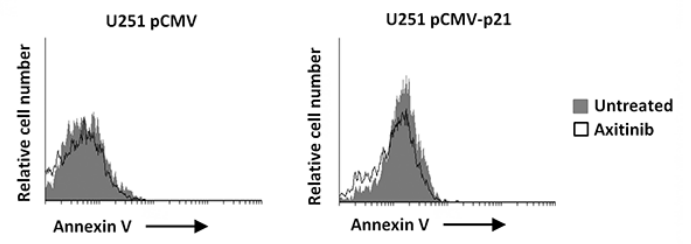

Figure 6: p21 overexpression decreases cell viability of axitinib-treated U251 glioma cells. A. Lysates from untransfected, pCMV and pCMV-p21 U251 cells were separated on SDS-PAGE and probed with specific rabbit anti-human p21 Ab. GAPDH protein levels were evaluated as loading control. Blots are representative of three separate experiments. B. Untransfected, pCMV and pCMV-p21 U251 cell viability was determined by MTT assay after $72 \mathrm{~h}$ of transfection. Data shown are the mean \pm SD of three separate experiments. $* \mathrm{p}<0.01$ vs untransfected and pCMV U251 cells. C. Representative cell cycle distribution in pCMV and pCMV-p21 U251 cells treated for $72 \mathrm{~h}$ with axitinib. D. U251 cells were treated as above described and then PI incorporation was analyzed by flow cytometry. Histograms are representative of one of three separate experiments. E. U251 cells were treated as above described and then Annexin V staining was analyzed by flow cytometry. Histograms are representative of one of three separate experiments. 
The fact that p21 was accumulated in all three cell lines cotreated with axitinib and bortezomib, further suggests that p21 may play an essential role in axitinibinduced cell death. Therefore, through RNA silencing (siRNA) technique we analyzed the p21 involvement in T98 cell line. After $72 \mathrm{~h}$ of transfection, when p21 expression is impaired by the specific siCDKN1A (Figure $8 \mathrm{E})$, both axitinib- and axitinib-bortezomib-induced cytotoxicity is reduced in siCDKN1A T98 cells respect to NC1 T98 cells, used as negative transfection control (Figure 8F, 8G).

Overall, bortezomib plus axitinib in combination increase p21 levels and sensitize glioma-sensitive and resistant cells to drug-induced cytotoxic effects by triggering senescence-associated cell death and necrosis, respectively.

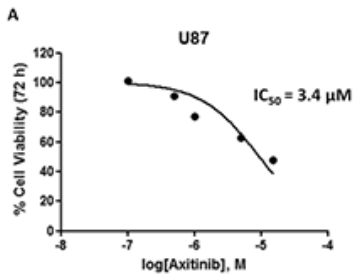

U87
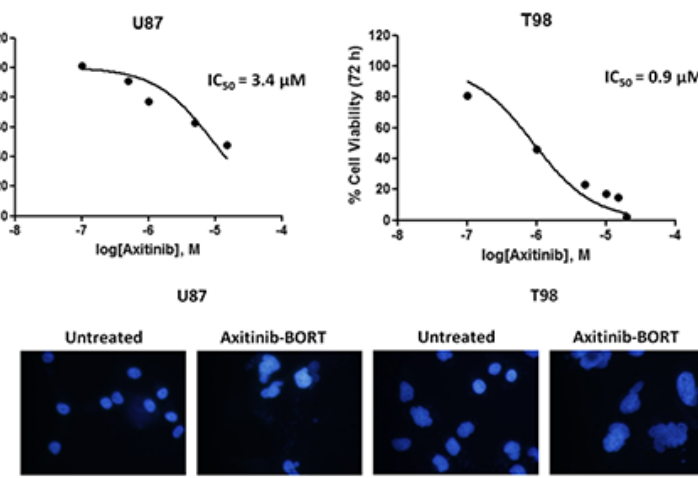

T98
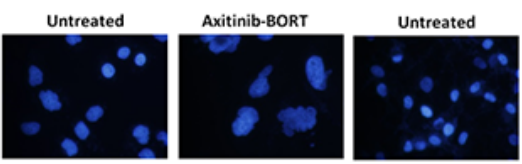

Axitinib-BORT

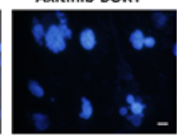

c
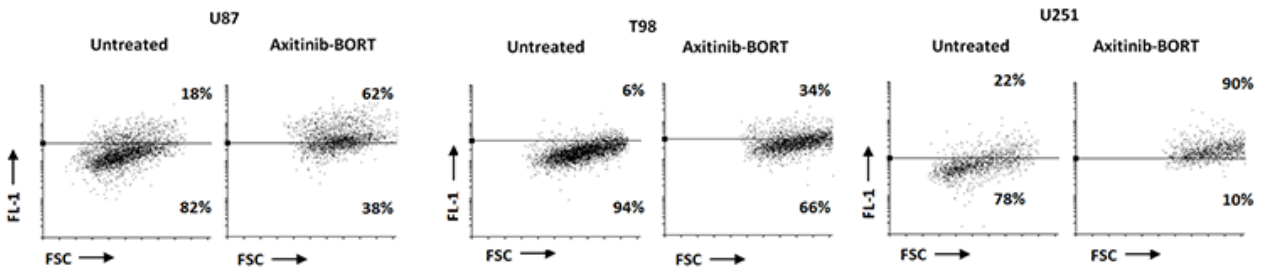

D
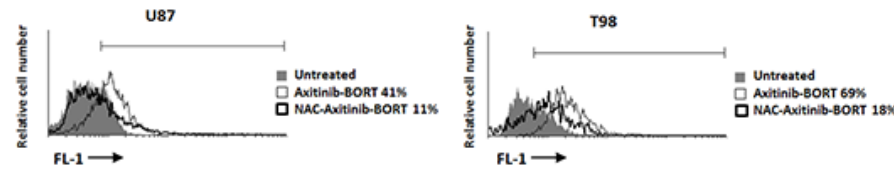
GAChinib-BORT 69\%
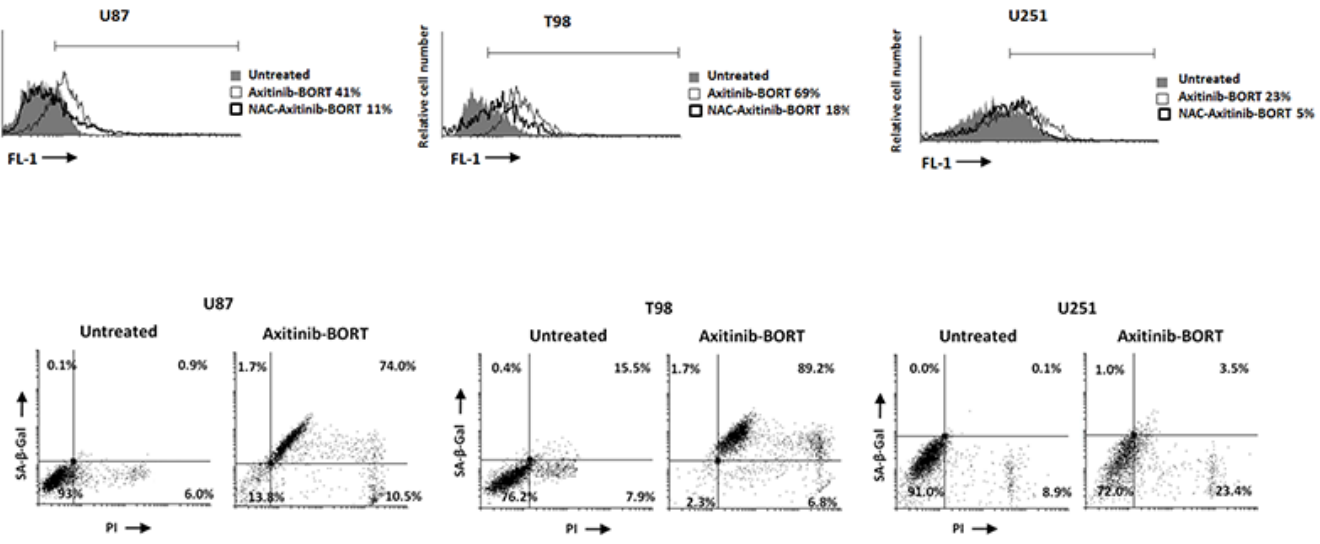

Figure 7: Cotreatment axitinib-bortezomib induces cell death also in axitinib-resistant U251 glioma cell line. A. U87, T98 and U251 glioma cell lines were cultured for $72 \mathrm{~h}$ with different doses of axitinib administred in combination with $2.5 \mathrm{nM}$ bortezomib. Cell viability was determined by MTT assay. Data shown are expressed as mean \pm SE of three separate experiments. B. Glioma cells were cultured for $72 \mathrm{~h}$ with the combination axitinib $(5 \mu \mathrm{M}$ for U87 and T98, $15 \mu \mathrm{M}$ for U251) - bortezomib (2.5 nM). Nuclei of treated cells were then stained with Hoechst 33258 and analyzed on ten random fields. Cells were observed under a fluorescence microscope. Bar: 50 $\mu \mathrm{M}$. C. Change in JC1 green (FL-1) respect to FSC parameter in cells treated with the combination axitinib-bortezomib as above described was detected by flow cytometer. D. ROS generation in glioma cell lines cotreated for $72 \mathrm{~h}$ with axitinib and bortezomib, pretreated or not with NAC $10 \mathrm{mM}$ for $1 \mathrm{~h}$. Cells were stained with DCFDA before flow cytometric analysis. Data are expressed as percentage of DCFDA positive cells with respect to untreated cells. E. Flow cytometric analysis on glioma cells cultured as above described was performed by $\mathrm{C}_{12} \mathrm{FDG}$ and PI double-staining. Data represent the percentage of PI and/or SA- $\beta$-galactosidase positive cells and are representative of one of three separate experiments. 


\section{DISCUSSION}

In this study, we describe that axitinib treatment affects glioma cell viability inducing the DDR. This response to genotoxic insults involves sensing of DNA damage by a class of protein kinases, including ATM,
ATR, followed by activation of Chk1 and Chk2 kinases that cause temporary cell cycle arrest, as well as promotes assembly of DNA repair complexes at the damaged sites at chromosomes [36]. The checkpoint regulators Chk1 and $\mathrm{p} 21$ were found to promote damage-induced mitotic catastrophe and a senescence-like phenotype [37].

A

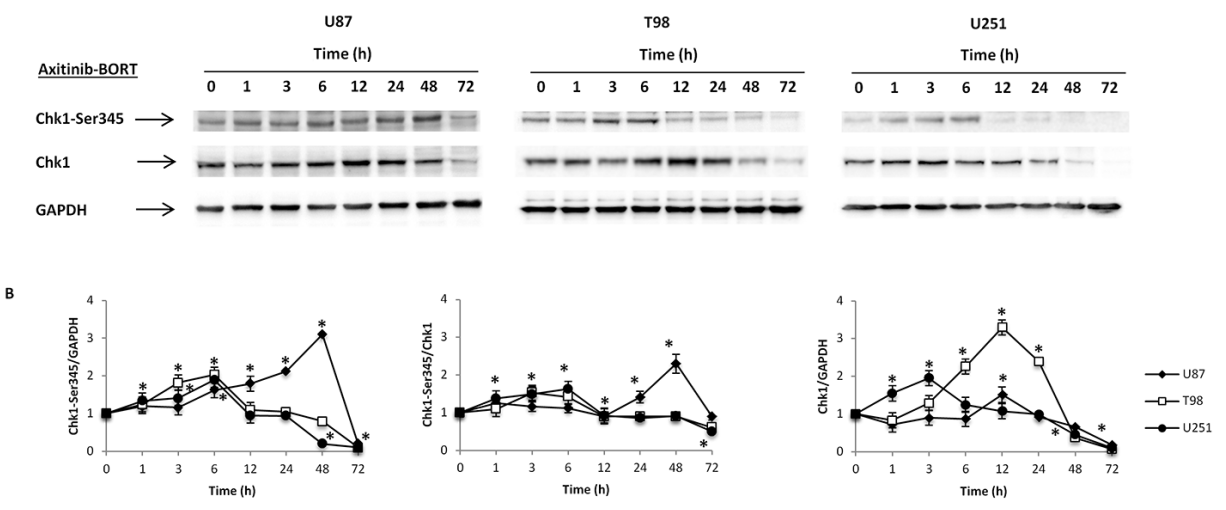

c
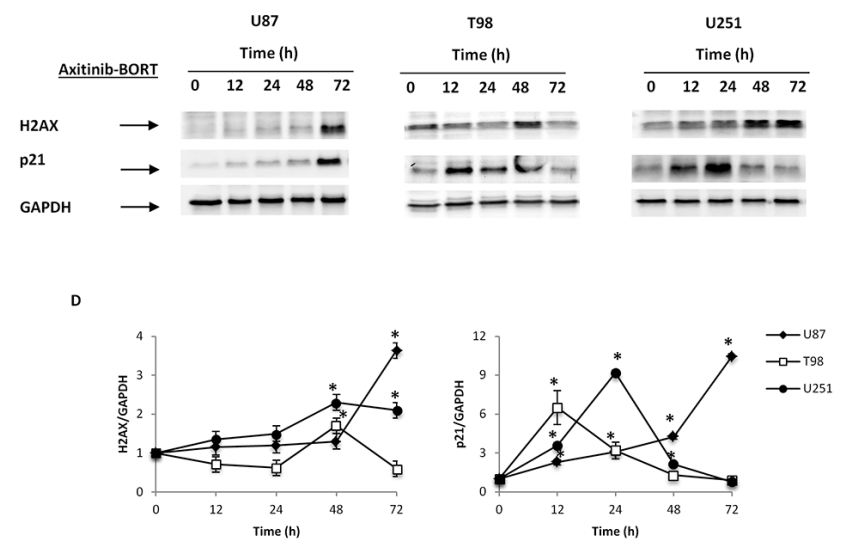

E

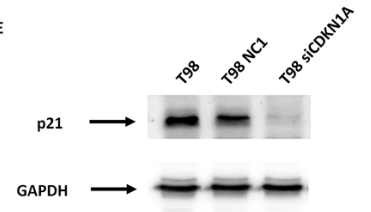

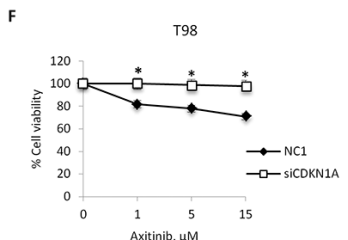

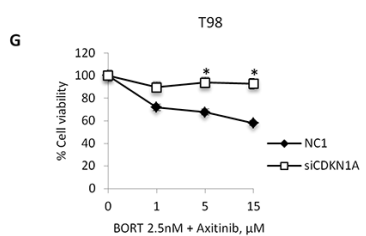

Figure 8: The role of p21 protein in axitinib-bortezomib induced cytotoxic effects. A. Western blot analysis of Chk1Ser345 and Chk1 protein levels in glioma cells after treatment with bortezomib $(2.5 \mathrm{nM})$ and axitinib $(5 \mu \mathrm{M}$ for U87 and T98, $15 \mu \mathrm{M}$ for U251). Blots are representative of one of three separate experiments. B. Chk1-Ser345 and Chk1 densitometry values were normalized to GAPDH used as loading control. The Chk1-Ser345 protein levels were also determined with respect to Chk1 levels. Densitometric values shown are the mean $\pm \mathrm{SD}$ of three separate experiments. ${ }^{*} \mathrm{p}<0.01 v s$ untreated cells. C. Western blot analysis of $\mathrm{H} 2 \mathrm{AX}$ and $\mathrm{p} 21 \mathrm{protein}$ levels in glioma cells after the axitinib-bortezomib combined treatment. Blots are representative of one of three separate experiments. D. Quantitative representation of the experiment reported in panel C. H2AX and p21 densitometry values were normalized to GAPDH used as loading control. Densitometric values shown are the mean $\pm \mathrm{SD}$ of three separate experiments. ${ }^{*} \mathrm{p}<0.01 v s$ untreated cells. E. Lysates from untransfected, NC1 (negative control) and siCDKN1A T98 cells were separated on SDS-PAGE and probed with specific rabbit antihuman p21 Ab. GAPDH protein levels were evaluated as loading control. Blots are representative of three separate experiments. F. NC1 and siCDKN1A T98 cell viability was determined by MTT assay after $72 \mathrm{~h}$ of axitinib treatment. Data shown are the mean \pm SD of three separate experiments. ${ }^{*} \mathrm{p}<0.01 v s \mathrm{NC1}$ transfected cells. G. NC1 and siCDKN1A T98 cell viability was determined by MTT assay after $72 \mathrm{~h}$ of axitinib-bortezomib cotreatment. Data shown are the mean $\pm \mathrm{SD}$ of three separate experiments. * $\mathrm{p}<0.01$ vs $\mathrm{NC} 1$ transfected cells. 
Here, we found that treatment of glioma cells with axitinib triggers the DDR, evidenced by increased levels of phosphorylated H2AX and Ser345-Chk1, leading to cell cycle arrest at G2/M phase and accumulation of polyploid glioma cells undergoing mitotic catastrophe. Moreover, in U87 and T98 cell lines, at later time points, when Ser345-Chk1 activation declines, the overexpression of the cell cycle inhibitor p21 activates a cell senescent program resulting in senescence-associated cell death and necrosis of treated cells. Conversely, a progressive increase of G2/M phase and an accumulation of polyploidy cells at 72 $\mathrm{h}$ after treatment were observed in U251 axitinib-resistant cells.

Numerous anti-tumor drugs, including DNA damaging agents, can induce mitotic catastrophe [25]. In particular, tetraploid tumor cells, intrinsically susceptible to mitotic aberrations, are sensitive to the induction of mitotic catastrophe [24, 25]. To detect the occurrence of mitotic catastrophe, both morphologic characteristics and presence of mitotic defects are used [38]. Originally, mitotic catastrophe was defined as a cell death-related process caused by aberrant mitosis. However, it has been now demonstrated that mitotic catastrophe represents a step preceding apoptosis or necrosis [24, 25]. In this regard, we found that axitinib induces mitotic catastrophe both in drug-sensitive U87 and T98 and -resistant U251 glioma cells. Indeed all glioma cell lines undergoing mitotic catastrophe show multinucleation and increased mitochondrial mass but only U87 and T98 cells die. Overall our findings support the hypothesis that mitotic catastrophe represents a step preceding a senescentassociated cell death.

At present two different types of cellular senescence have been demonstrated in vivo and in vitro. Replicative senescence represents a stable and long-term loss of proliferative capacity, despite continued viability and metabolic activity, due to telomere loss or dysfunction [33], and premature senescence, a type of DNA-damage senescent-associated cell death that arises at a stage before telomere shortening. This latter senescence program is induced by chemotherapeutic agents, oxidative stress, oncogenic or mitogenic signals [39-41,34], and results in reduced cell viability and induction of cell death through different cell death modalities despite the p53 status of the different cell lines. Indeed we evidenced an increased number of $\beta$-gal ${ }^{+} \mathrm{PI}^{+}$and $\beta$-gal-PI $\mathrm{I}^{+}$cells suggestive of senescent-associated necrosis and necrotic cell death in p53 wild-type U87 cells after axitinib exposure. In p53 mutant T98 cell line, the axitinib-treated cells showed a $\beta$-gal ${ }^{+} \mathrm{PI}^{+}$phenotype, sign of a senescence-associated cell death; no senescent cell death or necrosis were evidenced in axitinib-treated p53 mutant U251 cells.

DNA damage-induced senescent necrosis is caused by an excessive intracellular ROS generation that impairs DNA repair and cell signaling [32]. In this regard, a time-dependent increase of ROS generation was observed in axitinib-sensitive U87 and T98 cells; pretreatment with the anti-oxidant agent NAC, resulted in a decreased percentage of $\beta$-gal ${ }^{+} \mathrm{PI}^{+}$cells. On the contrary in U251 glioma cells, the inability of axitinib to trigger ROS signals, makes drug-treated cells resistant to premature senescence and cell death. Similarly, treatment of RCC cells and gastric cancer cells with axitinib, results in cell cycle arrest in G2 phase, and induces a ROS-dependent SA- $\beta$-galactosidase-positive senescent phenotype [7, 42].

Chk1 regulates DNA replication, cell cycle progression, chromatin remodeling and cell death. Here we found that Chk1 activation is associated with cell cycle arrest and mitotic catastrophe in all glioma cell lines tested. However, in axitinib-treated U87 and T98 cells, H2AX phosphorylation and Ser345-Chk1 activation transiently arrested cell cycle in G2/M, accumulated polyploid cells that underwent mitotic catastrophe and induced p21-driven senescent-associated cell death. In U251 cells axitinib treatment stably arrested cell cycle in G2/M and increased polyploid cells that underwent mitotic catastrophe as above described, but the failure to induce p21 overexpression rescued glioma cells to axitinibinduced cell death. Furthermore, we demonstrated that overexpression of p21 in U251 cells restores the sensitivity of glioma cells to axitinib and induces a necrotic cell death as shown by the typical DNA smear and the lack of procaspase- 3 activation. These data are in agreement with previous findings demonstrating that $\mathrm{p} 21$ is able to bind and inhibit the activity of proteins directly involved in the induction of apoptosis, including procaspase [43]. Further, the overexpression of the cell cycle inhibitor p21, at time of Chk1 activation shutdown, represented a prerequisite to drive glioma cells to death. Similarly, in PC-3 prostate cancer cells, retrovirus-mediated transduction of p21 induces cell death by suppressing Chk1 activation and DDR [42]. On the other hand, the silencing of p21 made T98 cells resistant to axitinib therapy confirming a pivotal role of p21 in the glioma cellular response to this TKI.

Bortezomib and the new proteasome inhibitor, marizomib, have been found to induce increased p21 levels in GBM [44]. The present study demonstrated that the advantageous schedule to treat glioma cells in vitro is the axitinib and bortezomib coadministration. We also characterized the molecular mechanisms involved in the synergistic effect between these drugs. We demonstrated that bortezomib when administered at nanomolecular, no toxic doses in combination with suboptimal dose of axitinib, promotes cytotoxic activity both in axitinibsensitive and -resistant glioma cell lines by increasing p21 protein levels, as supported by the p21 silencing experiments. The axitinib plus bortezomib synergistic effect was associated also with Ser345-Chk1 activation and H2AX phosphorylation mainly in U87 and U251 cell lines, although with different kinetics. This combined treatment induced mitotic catastrophe and ROS-mediated 
DNA-damage senescence-associated necrosis in U87 and T98 glioma cells. Interestingly in axitinib-resistant U251 cells, the administration of bortezomib made the cells sensitive to the TKI, by increasing Ser345-Chk1, H2AX phosphorylation and triggering p21 overexpression, with the induction of ROS-dependent necrosis. These results suggest that different levels of ROS and sensitivity of cells to drug-induced oxidative stress, may influence cell death modalities [32, 45]. Overall, these results demonstrated that H2AX, Ser345-Chk1 and p21 phosphorylation levels, as well as ROS generation induced by axitinib alone or in combination with bortezomib, promoted the sensitivity of glioma cells, and overcame the resistance, through the activation of different cell death outcomes.

Finally, although promising results were recently obtained by Duerinck et al. (increased 6-month PFS rate and median OS) in a randomized phase II trial [7], a longterm disease control or cures have not been still obtained in glioma patients. On the other hand, bortezomib has been recently demonstrated to sensitize glioma cells to apoptotic cell death in vitro $[21,22]$. However, also for the ability of high doses of bortezomib to stimulate the angiogenesis of glioma stem-like cells [22], the in vivo bortezomib-induced effects are conflicting. The efficacy of bortezomib in combination with chemotherapeutic drugs (e.g., tamoxifen, temozolomide) or radiotherapy is limited [46]. Thus, the need to improve the efficacy of treatment by constructing a rationally directed combination strategy to achieve meaningful anti-glioma activity represents a key point.

Although the extrapolation of in vitro data to the clinical setting should be considered with caution, our results obtained administering suboptimal dose of bortezomib demonstrated to not affect cell viability nor VEGFA expression, combined with low doses of the anti-angiogenetic TKI, axitinib may provide a rationale for the ongoing clinical investigation. Moreover, this combinatorial approach could be able to overcome the above-mentioned limitations by enhancing the cytotoxicity against glioblastoma.

\section{MATERIALS AND METHODS}

\section{Cell line culture}

The p53-wild type U87MG glioma cell line was obtained from American Type Culture Collection (LGC Promochem, Teddington, UK). The human p53-mutant T98 and U251 glioma cell lines were obtained from Cell Bank Interlab Cell Line Collection (ICLC, Italy). Glioma cells were grown in Eagle's Minimum Essential Medium (Lonza Bioresearch, Basel, Switzerland) supplemented with $10 \%(\mathrm{v} / \mathrm{v})$ heat-inactivated fetal bovine serum (FBS), $2 \mathrm{mM}$ L-glutamine and $100 \mathrm{IU} / \mathrm{ml}$ of penicillin, $100 \mu \mathrm{g}$ of streptomycin (Lonza), $1 \mathrm{mM}$ sodium pyruvate (Lonza) and non-essential amino acids (Lonza). Cell lines were maintained at $37^{\circ} \mathrm{C}, 5 \% \mathrm{CO}_{2}$ and $95 \%$ of humidity.

\section{Reagents}

Axitinib (Inlyta $\left.{ }^{\circledR}\right)$ was kindly provided by Pfizer (New York, NY). Bortezomib (BORT) was provided by Janssen-Cilag International N.V. (Beerse, Belgium). Mouse monoclonal anti-glyceraldehyde-3-phosphate dehydrogenase (GAPDH) Ab was from Origene (Rockville, MD). Mouse anti-p21 antibody (Ab) was purchased from Santa Cruz Biotechnology (Santa Cruz, CA). Rabbit antiphospho-histone H2AX (Ser139), anti-Chk1-Ser345, anti-Chk1 and anti-caspase-3 Abs were purchased from Cell Signaling Technology (Danvers, MA). The following secondary antibodies were used: horseradish peroxidase (HRP)-conjugated anti-mouse IgG and HRPconjugated anti-rabbit IgG (Cell Signaling Technology). Annexin V-fluorescein isothiocyanate (Annexin V-FITC) was purchased from eBioscience (Hatfield, UK). 5 -dodecanoylaminofluorescein di- $\beta$-D- galactopyranoside (C12FDG) were from Invitrogen (San Diego, CA, USA). Bafilomycin A1, dimethyl sulfoxide (DMSO, used as vehicle), Hoechst 33258, propidium iodide (PI), ribonuclease A, 5-bromo-4-chloro-3-indolyl $\beta$-D- galactopyranoside (X-Gal), N-acetyl-L-cysteine (NAC), 10-N-nonyl acridine orange (NAO) and 3-(4,5-dimethylthiazol-2-yl)-2,5diphenyltetrazolium bromide (MTT) were from Sigma Aldrich (St. Louis, MO). 5,5,6,6-tetrachloro-1,1,3,3tetraethyl benzimidazolylcarbocyanine iodide (JC-1) was from Invitrogen (Carlsbad, CA).

\section{MTT assay}

The colorimetric MTT assay was used to evaluate cell viability. Three $\times 10^{4}$ cells $/ \mathrm{ml}$ were seeded into 96 -well plates. After 1 day of incubation, compounds or vehicles were added. To evaluate the single-agent treatment, the cells were exposed to axitinib or bortezomib alone for up to $72 \mathrm{~h}$, and the half maximal inhibitory concentration $\left(\mathrm{IC}_{50}\right)$ was considered as the concentration resulting in $50 \%$ cell growth inhibition compared with the untreated control cells. To evaluate the cytotoxic effects of the combined treatment, the cells were treated with two different schedules: pretreated with axitinib for $72 \mathrm{~h}$, washed, replated and treated with bortezomib for $72 \mathrm{~h}$; treated concomitantly with axitinib and bortezomib for up to $72 \mathrm{~h}$. In some experiments cells that were treated with axitinib and/or bortezomib for $72 \mathrm{~h}$, were incubated in drug-free medium for $72 \mathrm{~h}$. Four replicates were used for each treatment. At the indicated time point, cell viability was assessed by adding $0.8 \mathrm{mg} / \mathrm{ml}$ of MTT to the media. After $3 \mathrm{~h}$ supernatants were discarded and coloured formazan crystals dissolved with $100 \mu \mathrm{l} /$ well of DMSO, were read by an enzyme-linked immunosorbent assay reader (BioTek Instruments, Winooski, USA). Four replicates were used for each treatment. Vehicle data were omitted since no effects were observed as respect to untreated cells.

Synergistic activity of the axitinib-bortezomib combination was determined by the isobologram and 
combination index (CI) methods (CompuSyn Software, ComboSyn, Inc. Paramus, NJ 2007). The CI was used to express synergism $(\mathrm{CI}<1)$, additivity $(\mathrm{CI}=1)$ or antagonism $(\mathrm{CI}>1)$ and was calculated according to the standard isobologram equation [47].

\section{Cell cycle analysis}

Three $\times 10^{4}$ glioma cells $/ \mathrm{ml}$ were treated with the appropriate drugs, collected and fixed in $70 \%$ ethanol and then washed with staining buffer (phosphate-buffered saline, PBS, $2 \%$ FBS and $0.01 \% \mathrm{NaN}_{3}$ ). Next, the cells were treated with $100 \mu \mathrm{g} / \mathrm{ml}$ ribonuclease A solution, incubated for $30 \mathrm{~min}$ at $37^{\circ} \mathrm{C}$, stained for $30 \mathrm{~min}$ at room temperature with PI $20 \mu \mathrm{g} / \mathrm{ml}$ and then analysed by flow cytometry using linear amplification.

\section{Western blot analysis}

Cells were lysed in lysis buffer containing protease inhibitor cocktail (Sigma Aldrich). Lysates were separated on $8-14 \%$ SDS polyacrylamide gel and transferred onto Hybond-C extra membranes (GE Healthcare). Membrane were incubated overnight at $4^{\circ} \mathrm{C}$ in primary Abs (antiphospho-H2AX 1:1000, anti-Chk1-Ser345 1:1000, antiChk1 1:1000, anti-p21 1:300, anti-caspase-3 1:1000, anti-GAPDH 1:8000), followed by the incubation (room temperature, $1 \mathrm{~h}$ ) with HRP-conjugated anti-rabbit or antimouse secondary Abs. Peroxidase activity was visualized with the LiteAblot ${ }^{\circledR}$ PLUS and LiteAblot ${ }^{\circledR}$ TURBO (EuroClone, Milan, Italy) kits and densitometric analysis was carried out by a Chemidoc using the Quantity One software (Bio-Rad, Hercules, CA).

\section{Senescence analysis}

We performed the senescence analysis by both microscope and flow cytometry to evaluate the senescence-associated $\beta$-galactosidase activity. Treated cells were fixed for $5 \mathrm{~min}$ at room temperature in $3 \%$ formaldehyde and incubated overnight at $37^{\circ} \mathrm{C}$ without $\mathrm{CO} 2$ with fresh $\mathrm{SA}-\beta$-Gal stain solution: $1 \mathrm{mg} / \mathrm{mL}$ X-Gal, $150 \mathrm{mM} \mathrm{NaCl}, 2 \mathrm{mM} \mathrm{MgCl} 2,40 \mathrm{mM}$ citric acid, $5 \mathrm{mM}$ sodium phosphate $(\mathrm{pH} 6.0), 5 \mathrm{mM}$ potassium ferrocyanide, and $5 \mathrm{mM}$ potassium ferricyanide. Senescent cells were identified as blue-stained cells by standard light microscopy. Photographs were acquired and analyzed by an Olympus BX51 microscope (Hamburg, Germany) using magnification 40x.

Relatively to flow cytometry, we performed the assay using the fluorogenic substrate $\mathrm{C}_{12} \mathrm{FDG}$. Drugtreated cells were incubated for $1 \mathrm{~h}$ at $37^{\circ} \mathrm{C}$ and $5 \% \mathrm{CO}_{2}$ with $100 \mathrm{nM}$ bafilomycin $\mathrm{A} 1$ in culture medium to induce lysosomal alkalinization at $\mathrm{pH} 6$ and, then, for $1 \mathrm{~h}$ with $33 \mu \mathrm{M}$ C12FDG. Samples were immediately analyzed using FACScan cytofluorimeter using the CellQuest software. The $\mathrm{C}_{12}$-fluorescein signal was measured on the FL-1 detector, and $\beta$-galactosidase activity was estimated as percentage of positive cells. Thereafter, in some experiments, cells were also incubated with $20 \mu \mathrm{g} /$ $\mathrm{ml}$ PI followed by biparametric FACS analysis using the CellQuest software.

\section{Mitochondria staining}

To determine mitochondrial mass mitochondrial staining was performed by 5,50,6,60-tetrachloro-1,10, 3,30-tetraehylbenzimidazolylcarbocyanineiodide (JC-1) staining [27]. Briefly, treated cells were incubated for 10 min at room temperature with $10 \mu \mathrm{g} / \mathrm{ml}$ of JC-1. Samples were analysed using a FACScan cytofluorimeter with CellQuest software.

To further support the JC1 assay, we used acridine orange 10-nonyl bromide (NAO), a metachromic dye that fluoresces at $533 \mathrm{~nm}$ [48]. Treated cells were incubated at $37^{\circ} \mathrm{C}$ for $30 \mathrm{~min}$ with $0.1 \mu \mathrm{M}$ of $\mathrm{NAO}$, washed and analyzed by flow cytometry.

\section{Annexin V and PI staining}

Cell death was evaluated using Annexin V-FITC and PI staining followed by flow cytometry and FACS analysis. Three $\times 10^{4}$ cells $/ \mathrm{ml}$ were treated with vehicle, axitinib and/or bortezomib for up to $72 \mathrm{~h}$. After treatment, cells were stained with $5 \mu \mathrm{l}$ of Annexin V-FITC and 20 $\mu \mathrm{g} / \mathrm{ml}$ PI for $10 \mathrm{~min}$ at room temperature and washed once with binding buffer (10 mM Hepes/NaOH pH 7.4, 140 $\mathrm{mM} \mathrm{NaCl}, 2.5 \mathrm{mM} \mathrm{CaCl}$ ). The percentage of positive cells determined over 10,000 events was analyzed on a FACScan cytofluorimeter using the CellQuest software.

\section{DNA fragmentation assay}

Glioma cells were treated as above described for up to $72 \mathrm{~h}$, and genomic DNA was extracted using the Apoptotic DNA Ladder detection Kit (Life Technologies Italia, Monza, Italia). The purified samples were then subjected to electrophoresis on a $1.25 \%$ agarose gel, and DNA was stained with ethidium bromide. Ultraviolet spectroscopy at $302 \mathrm{~nm}$ was used to obtain the results.

\section{ROS production}

Cells were cultured for up to $72 \mathrm{~h}$ with axitinib or vehicle. In some experiments, cells were preincubated for $3 \mathrm{~h}$ with 10 mM NAC. Cells were then washed with PBS, pulsed with DCFDA for $10 \mathrm{~min}$ at $37^{\circ} \mathrm{C}, 5 \% \mathrm{CO}_{2}$, and analyzed by FACScan cytofluorimeter using the CellQuest software.

\section{Immunofluorescence and microscopic analysis}

Cells cultured for up to $72 \mathrm{~h}$ were washed with PBS and fixed in 4\% formaldehyde for $10 \mathrm{~min}$ at room temperature. For nuclei analysis, cells were stained with 
Hoechst 33258 and examined by using the Olympus BX51 microscope. For morphological analysis, cells were stained with haematoxylin for $1 \mathrm{~min}$ and washed again before staining with eosin for 30 seconds. Slides were mounted with $50 \%$ glycerol, sealed and observed under Olympus BX51microscope.

\section{Cell transfection}

U251 cells were plated at a density of $2 \times 10^{5}$ cells/ $\mathrm{ml}$. After overnight incubation, transfections were achieved with $7.5 \mu \mathrm{l} / \mathrm{ml}$ of the reagent TransIT-X2 (Mirus MIR-6003, OriGene, Rockville, MD) and $2.5 \mu \mathrm{g} / \mathrm{ml}$ of pCMV-p21 or pCMV empty (pCMV) vectors according to the manufacturer's instructions. The cells were harvested at $72 \mathrm{~h}$ post-transfection for analysis. The efficiency of transfection was evaluated by western blot analysis.

\section{p21 silencing}

Small interfering RNAs (siRNAs) targeted to p21 (siCDKN1A) and a non-silencing siRNA (NC1) served as control were purchased from Integrated DNA Technologies (Leuven, Belgium). T98 cells were plated at a density of $2 \times 10^{5}$ cells $/ \mathrm{ml}$. After overnight incubation, transfections were achieved with $7.5 \mu \mathrm{l} / \mathrm{ml}$ of the reagent TransIT-X2 and $10 \mathrm{nM}$ of siCDKN1A or NC1 (negative control) according to the manufacturer's instructions. The cells were harvested at $72 \mathrm{~h}$ post-transfection for analysis. The efficiency of transfection was evaluated by western blot analysis.

\section{RT-PCR analysis}

Total RNA was extracted with the RNeasy Mini Kit (Qiagen), and cDNA was synthesized using the HighCapacity cDNA Archive Kit (Applied Biosystems, Foster City, PA) according to the manufacturer's instructions. Quantitative real-time polymerase chain reaction (qRTPCR) for VEGFA was performed using the iQ5 Multicolor Real-Time PCR Detection System (Bio-Rad, Hercules, CA). PCR reaction was performed with RT2SYBRGreen qPCT mastermix (Qiagen) using $1 \mu \mathrm{l}$ of cDNA for reaction, following the amplification protocol described in the manufacture's instruction. RT2 qPCR Primer assays (Qiagen) were used for target gene amplification. All samples were assayed in triplicates in the same plate. Measurement of GAPDH levels was used to normalize mRNA contents, and target gene levels were calculated by the $2^{-\Delta \Delta \mathrm{Ct}}$ method.

\section{Statistical analysis}

The statistical significance was determined by Student's t-test and by one way ANOVA. The statistical analysis of $\mathrm{IC}_{50}$ levels was performed using Prism 5.0a (Graph Pad).

\section{ACKNOWLEDGMENTS}

A special thanks to Dr. Daniele Tomassoni, School of Biosciences and Veterinary Medicine, University of Camerino, for hematoxylin/eosin staining.

\section{CONFLICTS OF INTEREST}

The authors declare no conflict of interest.

\section{GRANT SUPPORT}

This study was supported by AIRC IG 2014, cod. 15821. We thank Pfizer GMbH for kindly providind Axitinib.

\section{REFERENCES}

1. Mentlein R, Forstreuter F, Mehdorn HM, Held-Feindt J. Functional significance of vascular endothelial growth factor receptor expression on human glioma cells. J Neurooncol. 2004; 67: 9-18.

2. Kaur B, Khwaja FW, Severson EA, Matheny SL, Brat DJ, Van Meir EG. Hypoxia and the hypoxia-inducible-factor pathway in glioma growth and angiogenesis. Neuro Oncol. 2005; 7: 134-153.

3. Stupp R, Hegi ME, Mason WP, van den Bent MJ, Taphoorn MJ, Janzer RC, Ludwin SK, Allgeier A, Fisher B, Belanger K, Hau P, Brandes AA, Gijtenbeek J, et al. Effects of radiotherapy with concomitant and adjuvant temozolomide versus radiotherapy alone on survival in glioblastoma in a randomized phase III study: 5-year analysis of the EORTCNCIC trial. Lancet Oncol. 2009; 10: 459-466.

4. Cohen MH, Shen YL, Keegan P, Pazdur R. FDA drug approval summary: bevacizumab (Avastin) as treatment of recurrent glioblastoma multiform. Oncologist. 2009; 14: 1131-1138.

5. Tzogani K, Skibeli V, Westgaard I, Dalhus M, Thoresen H, Slot KB, Damkier P, Hofland K, Borregaard J, Ersbøll J, Salmonson T, Pieters R, Sylvester R, et al. The European Medicines Agency approval of axitinib (Inlyta) for the treatment of advanced renal cell carcinoma after failure of prior treatment with sunitinib or a cytokine: summary of the scientific assessment of the committee for medicinal products for human use. Oncologist. 2015; 20: 196-201.

6. Wells JC, Stukalin I, Norton C, Srinivas S, Lee JL, Donskov F, Bjarnason GA, Yamamoto H, Beuselinck B, Rini BI, Knox JJ, Agarwal N, Ernst DS, et al. Third-line Targeted Therapy in Metastatic Renal Cell Carcinoma: Results from the International Metastatic Renal Cell Carcinoma Database Consortium. Eur Urol. 2016. pii: S0302-2838(16)30258-5.

7. Morelli MB, Amantini C, Santoni M, Soriani A, Nabissi M, Cardinali C, Santoni A, Santoni G. Axitinib induces DNA damage response leading to senescence, mitotic 
catastrophe, and increased NK cell recognition in human renal carcinoma cells. Oncotarget. 2015; 6: 36245-36259. doi: 10.18632/oncotarget.5768.

8. Lu L, Saha D, Martuza RL, Rabkin SD, Wakimoto H. Single agent efficacy of the VEGFR kinase inhibitor axitinib in preclinical models of glioblastoma. J Neurooncol. 2015; 121: 91-100.

9. Duerinck J, Du Four S, Vandervorst F, D'Haene N, Le Mercier M, Michotte A, VanBinst AM, Everaert H, Salmon I, Bouttens F, Verschaeve V, Neyns B. Randomized phase II study of axitinib versus physicians best alternative choice of therapy in patients with recurrent glioblastoma. J Neurooncol. 2016; 128: 147-155.

10. Naujokat C, Sezer O, Zinke H, Leclere A, Hauptmann S, Possinger K. Proteasome inhibitors induced caspase-dependent apoptosis and accumulation of p21Wafl/Cip1 in human immature leukemic cells. Eur J Haematol. 2000; 65: 221-236.

11. Goldberg AL. Protein degradation and protection against misfolded or damaged proteins. Nature. 2003; 426: 895-899.

12. Almond JB, Snowden RT, Hunter A, Dinsdale D, Cain K, Cohen GM. Proteasome inhibitor-induced apoptosis of B-chronic lymphocytic leukaemia cells involves cytochrome c release and caspase activation, accompanied by formation of an approximately $700 \mathrm{kDa}$ Apaf-1 containing apoptosome complex. Leukemia. 2001; 15: 1388-1397.

13. Miller CP, Ban K, Dujka ME, McConkey DJ, Munsell M, Palladino M, Chandra J. NPI-0052, a novel proteasome inhibitor, induces caspase- 8 and ROS-dependent apoptosis alone and in combination with HDAC inhibitors in leukemia cells. Blood. 2007; 110; 267-277.

14. Hershko A. Roles of ubiquitin-mediated proteolysis in cell cycle control. Curr Opin Cell Biol. 1997; 9: 788-799.

15. Kane RC, Farrell AT, Sridhara R, Pazdur R. United States Food and Drug Administration approval summary: bortezomib for the treatment of progressive multiple myeloma after one prior therapy. Clin. Cancer Res. 2006;12: 2955-2960.

16. Frankland-Searby S, Bhaumik SR. The $26 \mathrm{~S}$ proteasome complex: an attractive target for cancer therapy. BBA. 2012;1825: 64-76.

17. Caravita T, de Fabritiis P, Palumbo A, Amadori S, Boccadoro M. Bortezomib: efficacy comparisons in solid tumors and hematologic malignancies. Nat Clin Pract Oncol. 2006; 3: 374-387.

18. Asklund T, Kvarnbrink S, Holmlund C, Wibom C, Bergenheim T, Henriksson R, Hedman H. Synergistic killing of glioblastoma stem-like cells by bortezomib and HDAC inhibitors. Anticancer Res. 2012; 32: 2407-2413.

19. Kardosh A, Golden EB, Pyrko P, Uddin J, Hofman FM, Chen TC, Louie SG, Petasis NA, Schönthal AH. Aggravated endoplasmic reticulum stress as a basis for enhanced glioblastoma cell killing by bortezomib in combination with celecoxib or its non-coxib analogue, 2,5-dimethylcelecoxib. Cancer Res. 2008; 68: 843-851.

20. Lin L, Gaut D, Hu K, Yan H, Yin D, Koeffler HP. Dual targeting of glioblastoma multiforme with a proteasome inhibitor (Velcade) and a phosphatidylinositol 3-kinase inhibitor (ZSTK474). Int J Oncol. 2014; 44: 557-562.

21. Vlachostergios PJ, Papandreou CN. Efficacy of low dose temozolomide in combination with bortezomib in U87 glioma cells: a flow cytometric analysis. Arch Med Sci. 2015; 11:307- 310.

22. Bota DA, Alexandru D, Keir ST, Bigner D, Vredenburgh J, Friedman HS. Proteasome inhibition with bortezomib induces cell death in GBM stem-like cells and temozolomide-resistant glioma cell lines, but stimulates GBM stem-like cells VEGF production and angiogenesis. J Neurosurg. 2013; 119: 1415-1423.

23. Rogakou EP, Pilch DR, Orr AH, Ivanova VS, Bonner WM. DNA double-stranded breaks induce histone H2AX phosphorylation on serine 139. J Biol Chem. 1998; 273: 5858-5868.

24. Vakifahmetoglu H, Olsson M, Zhivotovsky B. Death through a tragedy: mitotic catastrophe. Cell Death Differ. 2008; 15: 1153-1162.

25. Denisenko TV, Sorokina IV, Gogvadze V, Zhivotovsky B. Mitotic catastrophe and cancer drug resistance: A link that must to be broken. Drug Resist Updat. 2016; 24: 1-12.

26. Castedo M, Perfettini JL, Roumier T, Andreau K, Medema R, Kroemer G. Cell death by mitotic catastrophe: a molecular definition. Oncogene. 2004; 23: 2825-2837.

27. Jangamreddy JR, Ghavami S, Grabarek J, Kratz G, Wiechec E, Fredriksson BA, Rao Pariti RK, Cieślar-Pobuda A, Panigrahi S, Łos MJ. Salinomycin induces activation of autophagy, mitophagy and affects mitochondrial polarity: differences between primary and cancer cells. BBA. 2013; 1833: 2057-2069.

28. Mao Z, Ke Z, Gorbunova V, Seluanov A. Replicatively senescent cells are arrested in G1 and G2 phases. Aging (Albany NY). 2012; 4: 431-435. doi: 10.18632/ aging. 100467.

29. Collado M, Blasco MA, Serrano M. Cellular senescence in cancer and aging. Cell. 2007; 130: 223-233.

30. Roninson IB. Tumor cell senescence in cancer treatment. Cancer Res. 2003; 63: 2705-2715.

31. Ewald JA, Desotelle JA, Wilding G, Jarrard DF. Therapyinduced senescence in cancer. J Natl Cancer Inst. 2010; 102: 1536-1546.

32. Passos JF, Nelson G, Wang C, Richter T, Simillion C, Proctor CJ, Miwa S, Olijslagers S, Hallinan J, Wipat A, Saretzki G, Rudolph KL, Kirkwood TBL, et al. Feedback between p21 and reactive oxygen production is necessary for cell senescence. Mol Syst Biol. 2010; 6: 347.

33. Kuilman T, Michaloglou C, Mooi WJ, Peeper DS. The essence of senescence. Genes Dev. 2010; 24: 2463-2479. 
34. Ricci MS, Zong WX. Chemotherapeutic approaches for targeting cell death pathways. Oncologist. 2006;11: 342-357.

35. Jane EP, Premkumar DR, Pollack IF. Bortezomib sensitizes malignant human glioma cells to TRAIL, mediated by inhibition of the NF- $\{$ kappa $\}$ B signaling pathway. Mol Cancer Ther. 2011; 10: 198-208.

36. Maréchal A, Zou L. DNA Damage Sensing by the ATM and ATR Kinases. Cold Spring Harb Perspect Biol. 2013; 5: a012716.

37. Bunz F, Dutriaux A, Lengauer C, Waldman T, Zhou S, Brown JP, Sedivy JM, Kinzler KW, Vogelstein B. Requirement for p53 and p21 to sustain G2 arrest after DNA damage. Science. 1998; 282: 1497-1501.

38. Gonçalves AP, Máximo V, Lima J, Singh KK, Soares P, Videira A. Involvement of p53 in cell death following cell cycle arrest and mitotic catastrophe induced by rotenone. BBA. 2011; 1813: 492-499.

39. Robles SJ, Adami GR. Agents that cause DNA double strand breaks lead to enrichment and the premature senescence of normal fibroblasts. Oncogene. 1998; 16: 1113-1123.

40. te Poele, RH, Okorokov AL, Jardine L, Cummings J, Joel SP. DNA damage is able to induce senescence in tumor cells in vitro and in vivo. Cancer Res. 2002; 62: 1876-1883.

41. Unterluggauer H, Hampel B, Zwerschke W, Jansen-Durr P. Senescence-associated cell death of human endothelial cells: the role of oxidative stress. Exp Gerontol. 2003; 38: 1149-1160.

42. Gabai VL, O'Callaghan-Sunol C, Meng L, Sherman MY, Yaglom J. Triggering senescence programs suppresses Chk1 kinase and sensitizes cells to genotoxic stresses. Cancer Res. 2008; 68: 1834-1842.

43. Dotto GP. p21(WAF1/Cip1): more than a break to the cell cycle? Biochim Biophys Acta. 2000; 1471: M43-56.

44. Manton CA, Johnson B, Singh M, Bailey CP, BouchierHayes L, Chandra J. Induction of cell death by the novel proteasome inhibitor marizomib in glioblastoma in vitro and in vivo. Sci Rep. 2016; 6: 18953.

45. Masgras I, Carrera S, de Verdier PJ, Brennan P, Majid A, Makhtar W, Tulchinsky E, Jones GD, Roninson IB, Macip $\mathrm{S}$. Reactive oxygen species and mitochondrial sensitivity to oxidative stress determine induction of cancer cell death by p21. J Biol Chem. 2012; 287: 9845-9854.

46. Kubicek GJ, Werner-Wasik M, Machtay M, Mallon G, Myers T, Ramirez M, Andrews D, Curran WJ Jr, Dicker AP. Phase I trial using proteasome inhibitor bortezomib and concurrent temozolomide and radiotherapy for central nervous system malignancies. Int J Radiat Oncol Biol Phys. 2009; 74: 433-439.

47. Chou TC. Theoretical basis, experimental design, and computerized simulation of synergism and antagonism in drug combination studies. Pharmacol Rev. 2006; 58: 621-681.

48. Michael E. Widlansky, Jingli Wang, Sherene M. Shenouda, Tory M. Hagen, Anthony R. Smith, Tinoy J. Kizhakekuttu, Matthew A. Kluge, Dorothee Weihrauch, David D. Gutterman, Joseph A. Vita. Altered Mitochondrial Membrane Potential, Mass, and Morphology in the Mononuclear Cells of Humans with Type 2 Diabetes. Transl Res. 2010; 156: 15-25. 